【土木計画学研究・論文集 No.2 1985年 1 月】

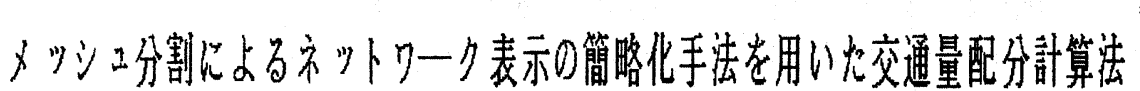

\author{
A TRAFFIC ASSIGNMENT METHOD BY SIMPLIFING \\ NETWORK REPRESENTATION OF MESH SUBAREAS
}

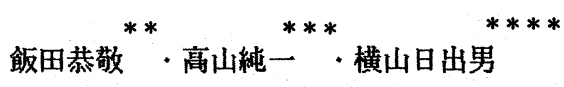

By Yasunori IIDA, Jun-ichi TAKAYAMA and Hideo YOKOYAMA

\begin{abstract}
This paper presents and discusses a traffic assignment method by simplifing network representation, in which the assignment calculation is performed alternately with the simplified network over the entire study area and with the detailed ( or real life) network in each of the divided mesh area. The aims of developement of this method are to reduce the computation time in the assignment and to attain high accuracy in estimation results. It is concluded through some numerical examples that the estimation errors for the simplified entire network and for the detailed network in each mesh are not significant if the degree of congestion is high and the number of iterations in incremental assignment is large.
\end{abstract}

1.はじめに

広域を対象とした大規模道路網の交通量配分を行 うには，膨大な計算機容量と計算時間を要するので 計算手法そのものの効率化をはかると同時にネッ トワーク表示の簡略化が必要となる。交通量配分に 関する研究は，これまで専ら前者に重点が置かれ， 幾多の重要な成果が得られてきた。しかし, 後者に ついての研究はきわめて少なく取り残されてきた観 がある。ネットワーク表示の簡略化として従来よく 用いられているのは，たとえば幹線道路などの主要 道路のみを表示し，その他の道路については省略す

\footnotetext{
* キーワーズ ; 交通量配分，ネットワーク简略化

** 正会員 工博 金沢大学教授 工学部建設工学科 （干920 金沢市小立野 2-40-20）

*** 正会員 工俈 金沢大学助手 工学部建留工学科 （广920 金沢市小立野 2-40-20）

****** 正会員 工仵（株）日本通運 中部重機建設支店 （广450 名古屋市中村区名駅南 4-11-20）
}

るという方法である。しかしこのような単純な方 法では，計算費用の節約には寄与しても，配分結果 に対する精度が保証されず，交通計画の基本デー夕 としての利用価値が減ずることになる。したがって 計算の経済化，効率化と同時にネットワークの合理 的表示方法か配分問題におけるこれからの重要な課 題といえる。

大規模道路網を対象とした解析手法とネットワー ク表示についての，これまでの研究を整理すると， 以下のように大きく 4 つに分類することができる。

1 つ目は，対象道路網を分割する考え方て，T.C. Huの方法 ${ }^{1)}$ や林等の方法 ${ }^{2)}$ など，いくつかの研究が なされている。しかしここれらの方法は計算の效率 化と節約化に主眼が置かれたものでありネネットワ 一ク表示の簡略化については言及されていない。特 に, 後者は多数のノードペア間の最短所要時間を求 めるためのもので，交通量配分に用いることを目的 とはしていない。 
2つ目は，ネットワークを階層化することにより 交通量配分を行う方法で，C.F.Daganzo の方法 ${ }^{3)}$ や 内山等の方法 ${ }^{4)}$ がある。Daganzo は道路を幹線道路 と非幹線道路に区分し，最短経路探索の計算勃率を 高める工夫を行った。しかし，配分計算では必ず幹 線道路を経てトリップが行なわれると仮定している ため, 幹線道路から成るネットワークの設定方法に 問題が残ると思われる。また，内山等は道路網の階 層化に加え，OD交通量も長トリップと短トリップ に階層化しており，配分計算ではまず長トリップを 幹線道路から成る特定ネットワークに配分し，その 後て短トリップを非幹線道路の集約による仮想ネッ トワークに配分している。しかし、この方法では幹 線道路と非幹線道路の整合性に問題があり，現害道 路網の詳細な配分結果を得ることは困難である。

3つ目は，ネットワークのリンク除去による方法 (枝村等の方法) $^{5)}$ である。この方法は, リンク除 去の基準（交通需要の小さいリンクから除去する） を明示的に取り扱った点では評価されるが，配分対 象道路網の簡略化に配分手法を用いなければならな いところに問題が残る。

4 つ目は，ネットワークを連続体あるいは理想道 路網と見なし、簡略化を行う方法 (C.F.Daganzoの 方法 ${ }^{6)}$, J.C.Tanner et alの方法 ${ }^{7)}$ ，G.F.Newellの 方法 $^{8)}$ ) であるが，抽象的なアグリゲーションを取 り扱ったものであり，現実道路網を対象とした実用 的手法とは言い難い。その他, 最近では交通量配分 だけではなく，交通機関分担も含めた形で簡略化を 行う非集計モデルによる新しい手法（N. Litinas and M.Ben-Akiva ${ }^{9)}$ ) む提案されている。

このように既存の各手法は，(1)計算技術の改良に 的を絞っている。(2)特定の用途を目的に開発されて いる。(3)非現実的な抽象モデルにとどまっている。 等の問題点を有しており，一般的な交通量配分手法 として用いるには限界がある。そこで本研究では， 計算機の経済的利用とネットワーク表示の簡略化を 同時に達成することをねらいとする新しい方法を提 案する。具体的には，対象道路網をメッシュ分割し， 各メッシュごとに詳細ネットワークと簡略ネットワ ークを作成して，交互に配分計算を繰り返す。この 方法により，対象域全体に対しても現実道路網のレ ベルで交通流の分析が可能となり，またメッシュ単
位に応じたマクロレベルでの交通挙動の把握もでき るようになる。特定のメッシュに対応する地域の交 通計画を策定したいときには，着目するメッシュの みを詳細ネットワークで表示し，他のメッシュは簡 略ネットワークで表示して解析すればよい。メッシ ュの形状や大きさは任意であるが，計画レベルやそ の目的を考虑して決定すればよい。さらに，この方 法はリンク交通量から現実道路網の交通流解析を行 うモデルにも利用することができ，現実の大規模道 路網に対する実用的計算手法の確立につながる。

本研究では, ネットワーク表示の簡略化の基本的 考え方を述へたあと，4 通りの配分計算法を示し， 仮想ネットワークに対する数值計算の結果をもとに 各計算法の特性と問題点を考察する。

2.ネットワーク表示の簡略化手法 ${ }^{10) \text { 212) }}$

ネットワーク表示を簡略化して配分計算を行う方 法としては，これまで様々なものが提案されている が、ここでは図一1に示すように対象道路網（全域 詳細道路網) をメッシュ分割し、メッシュごとに简 略ネットワークを作成して配分計算を行う新しい計 算法を提案する。この方法の特徵は，簡略化した全 域簡略道路網（図一2）を用いた全体配分と，その 配分結果をメッシュ内詳細道路網へ再配分する詳細 配分の 2 段階の配分計算（図一3）を交互に繰り返

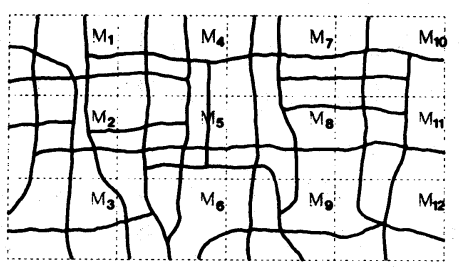

図一1 対象道路網とメッシュ分割 （全域詳細道路網）

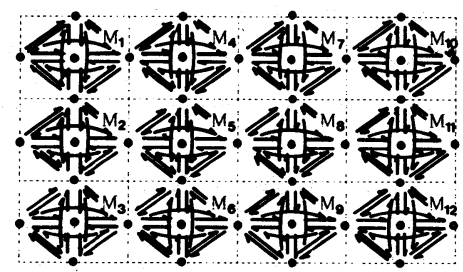

図一２全域簡略道路網 
すことにより，配分精度の保証と計算畤間の節約を 達成しようとするところにある。

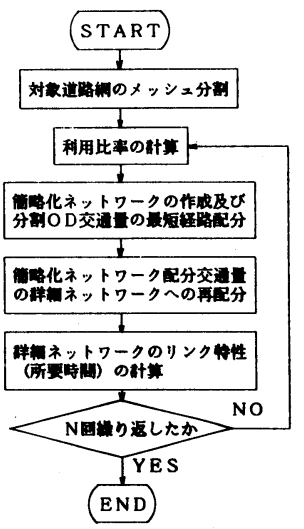

因一－简略化配分手法 の配分手順

ネットワークの簡略化はメッシュ内を通過する交 通とメッシュ内から発生, あるいはメッシュ内へ集 中する交通をそれぞれ1つの簡略アークで表示する ことにより行う。具体的には，図一4に示すように 1 つのメッシュには 1 個の集約ゾーンセントロイド (発着点 $N$ ) と 4 個の集約中継点 $A, B, C, D を$ 設定し，発 (着) ノード $\mathrm{N}$ と中継ノード $\mathrm{A}, \mathrm{B}, \mathrm{C}$ ， Dを結ぶ簡略アークを発 (着) アーク，中継ノード 間を結ぶ簡略アークを通過アークとしてネットワー ク表示する。ここで，ノードNはメッシュ内のゾー ンセントロイド $n_{i}$ （発生集中点）を集約したもの であり，ノード A，B，C，Dはそれぞれメッシュ 辺 $\mathrm{A}, \mathrm{B}, \mathrm{C}, \mathrm{D}$ 上の中継点 $a_{k}, b_{k}, c_{k}$, $d_{k}$ を集約したものである。

（1）発（着）アークおよび通過アークの作成方法 ノード $n_{i}$ から中継点 $a_{k}$ への最短所要時間を $t_{n_{i} a_{k}}$ とし，その経路を利用する確率 (利用比率) を $P_{n_{i} a_{k}}\left(\sum_{k} P_{n_{i} a_{k}}=1.0\right)$ とすると, ノード $n_{i}$ から中継ノードAへの平均所要時間 $t_{n_{i} A}$ は 式（1）で表すことができる。

$$
t_{n_{i} A}=\sum_{k} t_{n_{i} a_{k}} \cdot P_{n_{i} a_{k}}
$$

ここで，各ノード $n_{i}$ の発生交通量比率 $W O_{n_{i}}$ $\left(=O_{i} / \sum_{j} O_{j}, O_{i}\right.$; 発生交通量) を用いて, アーク所要時間の重みづけを行うと,ノードNから 中継ノードAへの平均所要時間 $t_{N A}$ (発アーク所要
時間)は式（2）のように表される。

$$
t_{N A}=\sum_{i} t_{n_{i} A} \cdot W O_{n_{i}}
$$

同様にして，中継ノードAからノードNへ の平均所要時間 $t_{A N}$ (着アーク所要時間) も，集中交通量比率 $W D_{n_{j}}\left(=D_{j} / \sum_{i} D_{i}\right.$ $D_{j}$; 集中交通量）を用いることにより表す ことができる。なお，中継ノード B， C，D についても同様である。

一方, 通過アークについてはメッシュ辺A 全体から流入し,メッシュ辺C全体へ流出す る通過交通量 $F_{A C}$ のう方, 中継点 $a_{k}, c_{k}$ を通過する交通量を $f_{a_{k} c_{k^{\prime}}}$ とすると，その 利用比率 $P_{a_{k} c_{k}}$ ，は式（3）で表される。

$$
P_{a_{k} c^{\prime}}=\frac{f_{a_{k} c_{k^{\prime}}}}{F_{A C}}=\frac{f_{a_{k} c_{k^{\prime}}}}{\sum_{k k^{\prime}} f_{a_{k} c_{k^{\prime}}}}
$$

ここで， $a_{k} ， c_{k}$ 間の最短所要時間を $t_{a_{k} c_{k}}$ とすると，通過アーク $L_{A C}$ の平均所要時間は，式 （4）のように表すことができる。他の通過アーク についても同様である

$$
t_{A C}=\sum_{k k^{\prime}} t_{a_{k} c_{k^{\prime}}} \cdot P_{a_{k} c^{\prime}}
$$

しかし，利用比率は一般に未知であるためここ では，次に示すようないくつかの仮定により利用比 率を設定し，簡略化を行う。

（2）利用者運転特性の仮定による利用比率計算法 ( 従来法 $)^{10)}$

一般に，道路利用者の経路選択は様々であるが， 概ね所要時間が短く，走行速度の速い混雑していな い道路を選択するものと考えられる。そこで，次の ような仮定を設定して利用比率の計算を行った。

仮定 $1 \cdots \cdots$ 利用比率は所要時間 $\left(t_{n_{i} a_{k}}, t_{a_{k} c_{k^{\prime}}}\right)$ の逆比に比例する。

$$
P_{n_{i} a_{k}}=\frac{\left(1 / t_{n_{i} a_{k}}\right)^{\gamma}}{\sum_{k}\left(1 / t_{n_{i} a_{k}}\right)^{\gamma}}
$$

仮定 $2 \cdots \cdots$...利用比率は平均速度 $\left(v_{n_{i} a_{k}}, v_{a_{k} c_{k^{\prime}}}\right)$ に比例する。

$$
P_{n_{i} a_{k}}=\frac{v_{n_{i} a_{k}}{ }^{\beta}}{\sum_{k} v_{n_{i} a_{k}{ }^{\beta}}}
$$


仮定 $3 \cdots \cdots$-...利用比率は平均速度と余裕交通容量

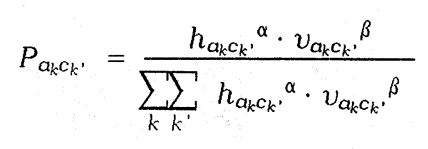$$
\left(h_{n_{i} a_{k}}, h_{a_{k} c_{k^{\prime}}}\right) \text { の積に比例する。 }
$$

仮定 4 …-利用比率は所要時間の逆比と余裕交通 容量の積に比例する。

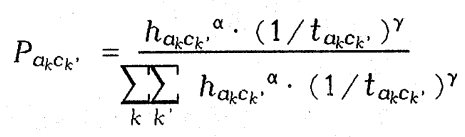

ここで，余裕交通容量 $h_{a_{k} c_{k}}$ とは，各経路区間 の交通容量から配分交通量を引いた最小值のことて ある。 $\alpha, \beta, \gamma$ はパラメー夕とする。

（3）交通量の連続性を考慮した利用比率計算法

\section{(連続条件法 $)^{11)}$}

各メッシュごとに，利用者運転特性を仮定して求 めた利用比率をそのまま用いて簡略化配分を行うと， ゾーン境界（メッシュ辺）上で交通量が不連続とな る。これは交通量の連続性を考虑せずに利用比率を 計算し、詳細ネットワークへの配分比率として用い ているためである。そこで，ここではゾーン境界上 のリンクで交通量の連続性が保たれるように，断面 交通量 $R X_{a_{k}}$ （観測されていないときにはリンク交 通容量 $C_{a_{k}}$ ) の比率を用いて配分比率を修正する 方法を提案する。

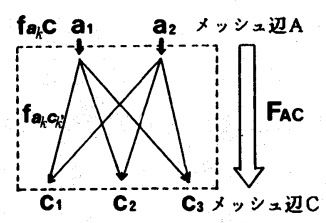

図一6 通過交通量の表示

図一6において，通過交通 $F_{A C}$ を考える。この とき，中継点 $a_{k}$ 多ら流入し，メッシュ辺C全体へ 流出する交通量 $f_{a_{k} C}=\sum k^{\prime} f_{a_{k} c^{\prime}}$ 如断面交通量 $R X_{a_{k}}$ の比率 $\left(R X_{a_{k}} / \sum_{k} R X_{a_{k}}\right)$ て流入側中継点 $a_{k}$ を通過すると仮定する（式（9））。同様に， $f_{A c_{k^{\prime}}}$ (メッシュ辺A全体から流入した交通量のうち 中継点 $c_{k^{\prime}}$ を通過する交通量, $\sum_{k} f_{a_{k} c_{k^{\prime}}}$ ） は断面 交通量 $R X_{c_{k^{\prime}}}$ の比率 $\left(R X_{c_{k^{\prime}}} / \sum_{k^{\prime}} R X_{c_{k^{\prime}}}\right)$ て流出側 中継点 $c_{k}$ 学通過すると仮定する（式（10））。

ここで， $f_{a_{k} C}$ のうち中継点 $c_{k^{\prime}}$ を通過する確率
を $Q_{a_{k} c_{k}}$ とすると，式（11）が成り立つ。

$$
\begin{aligned}
& f_{a_{k} C}=F_{A C} \cdot \frac{R X_{a_{k}}}{\sum_{k} R X_{a_{k}}}\left(=F_{A C} \cdot \frac{C_{a_{k}}}{\sum_{k} C_{a_{k}}}\right) \\
& f_{A c_{k^{\prime}}}=F_{A C} \cdot \frac{{ }^{2} X_{c_{k^{\prime}}}}{\sum_{k^{\prime}} R X_{c_{k^{\prime}}}}\left(=F_{A C} \cdot \frac{C_{c_{k^{\prime}}}}{\sum_{k^{\prime}} C_{c_{k^{\prime}}}}\right)
\end{aligned}
$$

$F_{A C} \cdot P_{a_{k} c_{k^{\prime}}}=f_{a_{k} C} \cdot Q_{a_{k} c_{k^{\prime}}}$

ただし， $Q_{a_{k} c_{k}}$ は式（5)，あるいは式（6）に より設定する。式（11）に，式（9）を代入すると 式（12）が得られる。

$$
P_{a_{k} c^{\prime}}=\frac{R X_{a_{k}}}{\sum_{k} R X_{a_{k}}} \cdot Q_{a_{k} c^{\prime}}
$$

式（12）は流入側の仮定を満たすが，流出側の仮 定は满たさない。そこで，流出側の仮定も同時に満 たすように， $P_{a_{k} c_{k}}$ の修正を行う。なお, メッシュ 内からの発生交通量, メッシュ内への集中交通量に ついても，同様にして配分比率の修正を行うことが でき。

\section{（4）輸送計画問題の導入による利用比率計算法 (輸送計画法 $)^{12)}$}

分割配分法 ( I A 法) は, 各配分段階において最 短経路へ分割OD交通量を配分する方法である。し たがって，各配分段階においては綕走行時間が最小 になるように交通量配分が行われる。それゆえこ こでは近似的にメッシュ内総走行時間が最小になる ように経路選択が行われるとして配分を行う。そう すると，この問題は最短所要時間 $t_{a_{k} c_{k}}$ を輸送コス トとした輸送計画問題（式 (13) の目的関数最小化 問題) として定式化することができる。ただし，制 約条件は $f_{a_{k} c_{k}} \geqq 0$ と式 (9)，式 (10) に示す 流入側，流出側の条件式である。したがって，シン プレックス法を用いれば簡単に解を求めることがて きる。なお，発 (着) アークの利用比率は断面交通 量 (交通容量) の代わりに, 発生 (集中) 交通量の 比率を用いれば，同様にして計算できる。

$$
G=\sum_{k} \sum_{k^{\prime}} t_{a_{k} c_{k^{\prime}}} \cdot f_{a_{k} c_{k^{\prime}}} \rightarrow \text { Min. }
$$

（5）配分比条件の仮定による利用比率計算法 （配分比条件法） ${ }^{12}$ )

各配分段階における利用比率 $P_{a_{k} c_{k}}$ の真実值は 全域詳細道路網に対して交通量配分を行ったときに 
得られる。しかし，詳細ネットワーク全体に対して 最短経路探索を行うのでは，簡略化の意味がなくな るので,ここでは着目したメッシュとその前後の隣 接メッシュ間 (図一7) でネットワークを作成して 交通量配分（ただし，配分に用いるOD表は隣接し たメッシュ間のOD交通量である）を行い，得られ た利用比率を用いて簡略ネットワークを作成する方 法を提案する。

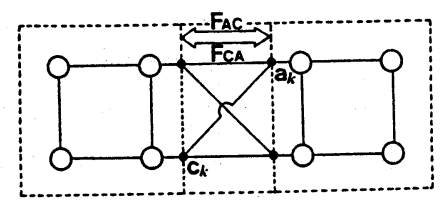

图一7通過アークの利用比率計算ネットワーク

この方法は，配分比条件の成立を仮定したものて あり、ネットワーク全体での経路選択が部分的に見 た場合の経路選択に近似できるとしたものである。 したがって，ネットワーク全体を対象とした経路探 索は全域簡略道路網を用いて行い,メッシュ内詳細 道路網に対しては着目メッシュを順次入れ換えて交 通量配分を行うだけでよい。中えに，通過アークの 場合は前後左右 4 方向に対して交通量配分を行い, 発（着）アークの場合には着目メッシュと前後左右 それぞれ1つずつの隣接メッシュ間(図一8)で交 通量配分（利用比率の計算）を行えばよい。このよ うにすることにより，交通量配分（経路探索）の簡 略化が可能となる。

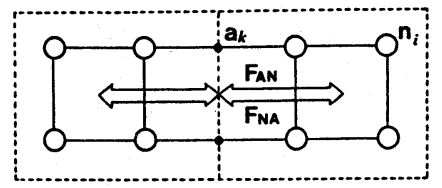

図一8 発着アークの利用比率計算ネットワーク

3. 簡略化のためのゾーン分割の方法と計算効率

一般に,メッシュ分割を大きくし、メッシュの数 $m$ を少なくすると，全域简略道路網での経路挆索 は効率的になるが、メッシュ内詳細道路網での計算 効率はそれほど向上しない。逆にメッシュの数を 多くすると，仮設中継ノード数が多くなり，全域簡 略道路網での計算効率が低下する。ここでは，1つ のメッシュに含まれるノード数（ゾーンセントロイ
ド数の平均值 $\bar{n}$, 通過ノード数の平均值 $\left.\bar{n}_{0}\right)$ と 分割の形状 (メッシュ辺の数 $n_{L}$ ) が, 簡略化にど れほど寄与するかについて检討を行う。ただし，勃 率性の計算は最短経路探索に要する計算回数 (1つ のノードより出るリンク数が一定のとき，ノード数 の約.2 乗のオーダーとなる) を用いて行う。

（1）簡略化を行わない場合の計算回数

対象地域全体のノード数Nは，メッシュ内の平均 ノード数 $\left(\bar{n}, \bar{n}_{0}\right)$ を用いると，ほぼ $N \fallingdotseq$ $m_{z} \cdot\left(\bar{n}+\bar{n}_{0}\right)$ になる。したがって, 最短経路探索 のための計算回数Wは概算的に式（14）となる。

$$
W=m_{z} \cdot \bar{n} \cdot\left\{m_{z} \cdot\left(\bar{n}+\bar{n}_{o}\right)\right\}
$$

（2）簡略化を行った場合の計算回数

簡略化配分を行う場合には，メッシュ内詳細道路 網で利用比率の計算 (WP ) と全域簡略道路網に おける配分計算（WS）が必要となる。

利用比率の計算には，メッシュ内各ノード間の最 短所要時間が必要となる。したがって，その計算回 数 $W_{P}$ はメッシュ内ノード数 $N_{p}=\bar{n}+\bar{n}_{\mathrm{o}}+n_{B} / \lambda$ を用いて， $W_{P}=m_{z} \cdot N_{p}{ }^{2}$ のように表すことがて きる。ただし、メッシュ境界上の中継ノードについ ては，接続リンク数入により重みづけを行った。

全域簡略道路網におけるノード数 $N_{S}$ は， $N_{S}=$ $m_{z} \cdot\left(1+n_{L} / 2\right)$ (中継ノード $n_{L}$ が隣接メッシュ 間で共有)となる。したがって，全域簡略道路網に おける計算回数 $W_{S}$ は， $W_{s}=m_{z}{ }^{2} \cdot\left(1+n_{L} / 2\right)$ となる。したがって，簡略化配分計算全体 $W_{M}$ では 次のようになる。

$$
\begin{aligned}
W_{M} & =W_{p}+W_{s} \\
& =m_{z} \cdot\left(\bar{n}+\bar{n}_{o}+\frac{n_{B}}{\lambda}\right)^{2}+m_{z} \cdot\left(1+\frac{n_{L}}{2}\right)
\end{aligned}
$$

ここで，簡略化配分が有効となるのは，W>WM のときである。したがって、この条件を満足する $m_{z}$ (下限值) は式 (16) で表される。

$$
m_{z}>\frac{2\left(\bar{n}+\bar{n}_{0}+n_{B} / \lambda\right)}{2 \bar{n}\left(\bar{n}+\bar{n}_{0}\right)-\left(n_{L}+2\right)}
$$

一方，簡略化表示のもう一つの目的は，ノード数 リンク数を減らし、計算機容量を削減することにあ る。したがって，詳細道路網全体のノード数 $N \leftrightharpoons$ $m_{z} \cdot\left(\bar{n}+\vec{n}_{0}\right)$, リンク数 $L \leftrightharpoons 2 m_{z} \cdot\left(\bar{n}+\bar{n}_{0}\right)$ よ 
りも，簡略化した場合のノード数 $N_{s}=m_{z} \cdot(1+$ $\left.n_{L} / 2\right)$, リンク数 $L_{s}=m_{z} \cdot\left(n_{L}+1\right) \cdot n_{L} / 2$ を少 なくする必要がある。よって，その条件は式 (17)， 式（18）となる。ただし，交差点は十字路を基本と して考えた。

$$
\begin{aligned}
\bar{n}+\bar{n}_{0} & >1+n_{\mathrm{L}} / 2 \\
4\left(\bar{n}+\bar{n}_{0}\right) & >\left(n_{\mathrm{L}}+1\right) \cdot n_{\mathrm{L}}
\end{aligned}
$$

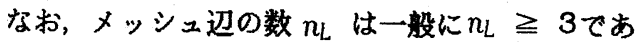
るため，式（18）.の条件式だけで分である。ゅえ に，簡略化のためのメッシュ分割は式 (18) を満足 するように行わなければならない。

\section{4. 簡略化配分法の適用性の检討}

簡略化配分法の推計精度に影蚃を及ぼす要因とし ては，(1)簡略化ネットワークの作成および詳細ネッ トワークへの配分に用いる利用比率 (パラメータ) の設定方法，(2)簡略化のためのメッシュ分割の大き さ, (3)分割配分回数，(4)ネットワークの形状とその 特性（交通容量と容量関数），(5)OD交通量の大き さとODパターン, などが考えられる。この中で, (4)，(5)は対象地域によって決まるものであり，(1)〜 (3)は解析の手軽さ，精度など計画目的に応じて決定 されるものである。

ここでは，シミュレーションを用いて簡略化配分 法の推計精度を分析し，その適用性を検討する。分 析には，図一 9 に示す格子状の対象道路網を用いた ただし，NET1，NET2，NET3 はノード1 ひノード 31のメッシュ区分 (1)〜（9）に含まれる道路網 を対象として、リンク所要時間とリンク交通容量を
3 通りに変えて設定した道路網であり，NET4 は周 辺ノード37〜60を含めて作成した道路網である。

OD交通量の大きさ，ODパターンの特徽を示す 指標として, リンクの混雑率 (平均值 $\gamma_{c}$ ) , メッ シュ内のゾーン内々率 (平均值 $\gamma_{0}$ ) と通過率 (平 均値 $\gamma_{T}$ ) を用いた。なお, 走行時間閔数（容量関 数）は式（19）を用い，愦差は真実值 $R X_{k}$ （全域

$$
t_{k}=t_{k}^{0}+10\left(\frac{E X_{k}}{C_{k}}\right)^{4}
$$

ここで, $t_{k} ;$ ；ンク $\mathrm{k}$ の所要時間 $t_{k}^{0} ;$ ⿰リンク $\mathrm{k}$ の初期所要時間 $E X_{k} ;$ リンク $\mathrm{k}$ の配分交通量 $C_{k} \quad$; リンク $\mathrm{k}$ の交通容量

$$
\delta=\sqrt{\frac{1}{R X} \sum_{k} \frac{\left(E X_{k}-R X_{k}\right)^{2}}{R X_{k}}}
$$

ただし $\quad R X=\sum_{k} R X_{k}$

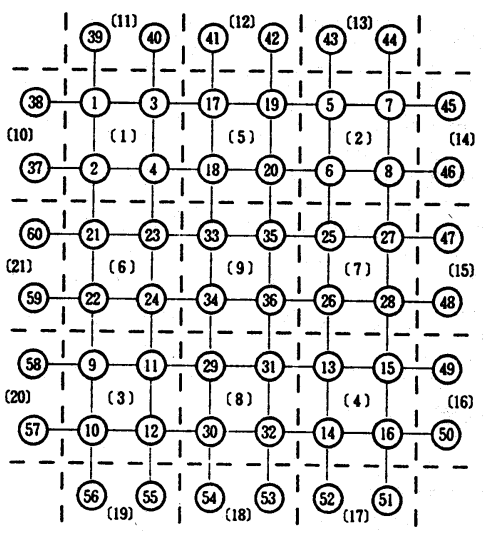

因一-9数值計算に用いた対象道路網とメッシュ分割

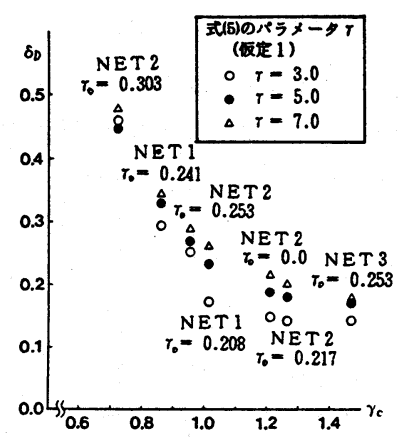

(a) 仮定 1

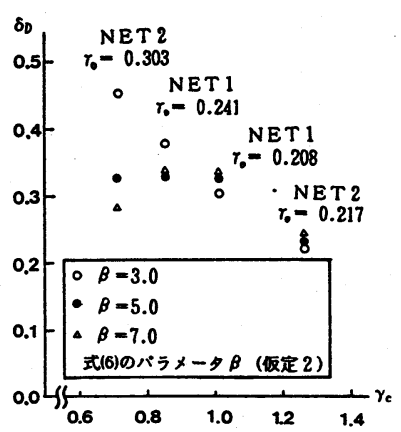

(b) 仮定 2

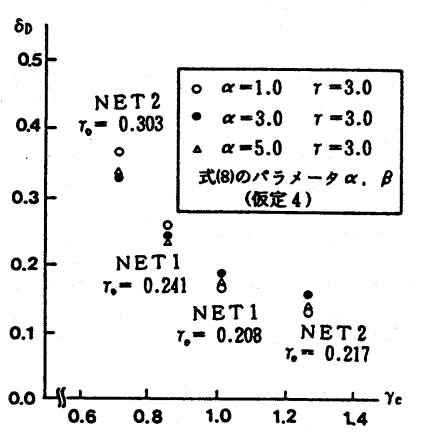

(c) 仮定 4

図一10 平均混雑率 $\gamma_{c}$ が推計精度 $\delta_{D}$ に及ぼす影艟 （配分比率の供正無し） 
詳細道路網に対して簡略化せずに配分した配分交通 量）に対する重み付き標準比率誤差（式（20） で表示する。

\section{（1）平均混雑率が推計精度に及ぼす影響}

利用比率の仮定式を代えて行ったシミュレーショ ン結果（分割配分回数 5 回）を図一10((a)仮定 1 , (b)仮定 2，(c)仮定 3）に示す。仮定式中のパラメー 夕の值によって推計精度は多少異なるが，全体的傾 向としては平均混雑率 $\gamma_{\mathrm{c}}$ が大きくなると推計精度 が良くなる傾向にある。これは，分割回数が少ない と， $\gamma_{c}$ が小さい場合に各配分段階における最短経 路が特定の経路に集中するのに対し， $\gamma_{c}$ が大きい 場合は最短経路が変化し，交通量がネットワークに 分散するからである。

（2）利用比率の設定方法の違いによる影響

図一10に示すように, 式 (5) 〜式 (8) の仮定 式をそのまま用いたのでは， $\gamma_{c}$ が小さい道路網に 対しては適用が困難である。この理由の一つは， $\gamma_{c}$ が小さい場合, 詳細ネットワークへ再配分したとき のメッシュ境界上ての配分交通量が隣接メッシュ間 で異なるためと考えられる。

そこで，交通量の連続性を考虑して配分比率の修 正を行った。結果を図一11（仮定 1) に示す。この 図より，交通量の連続性を考虑すれば平均混雑率 $\gamma_{c}$ が小さい場合でも，かなり精度が良いといえる。

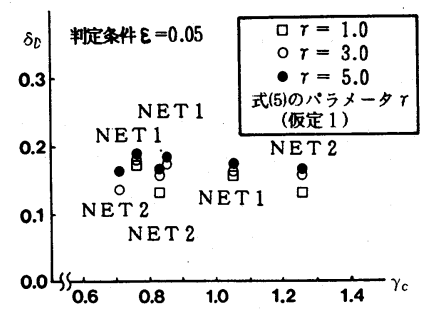

図-11 平均混雑率 $\gamma_{c}$ が推計精度 $\delta_{D}$ に及ぼす影薑 （配分比率の悠正有り）

図一 12 ，従来法（仮定 $1 ， r=3.0$ ），配分比 条件法, 輸送計画法を用いた場合の結果 (NET4) を 比較して示す。図上り, 配分比条件法, 輸送計画法 においても平均混雑率 $\gamma_{c}$ が大きくなると, 推計精 度が良くなる傾向にあることがわかる。特に，配分 比条件法は $\gamma_{0}$ が小さい場合でも, 従来法, 輸送計 画法に比べ推計精度が良いといえる。これは，今回
用いた対象道路網が比較的小さいため，配分比条件 の仮定がかなり成立しているためと考えられる。

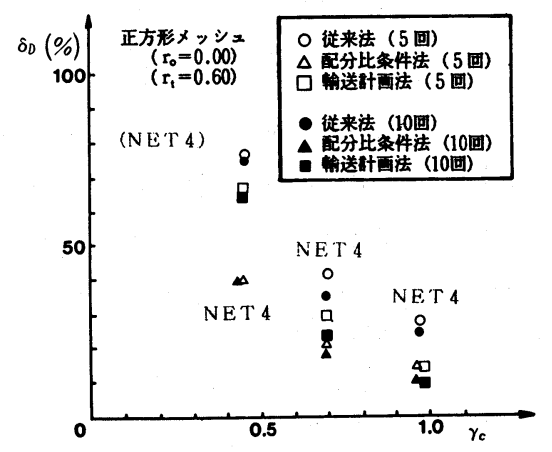

図一12 各简略化配㘧法の推計精度 $\delta_{0}$ の比較

（3）分割配分回数が推計精度に及ぼす影響

分割配分回数の違いが推計精度にどのような影響 を及ぼすかについて検討を行った。結果の一例を図 一13に示す。図には分割配分回数を 5 回（白抜き） としたときと10回（黒塗り）としたときの誤差をそ れぞれ絴軸（簡略ネットワークにおける誤差 $\delta_{S}$ ） と横軸（詳細ネットワークにおける鿁差 $\delta_{D}$ ) にと って示してある。

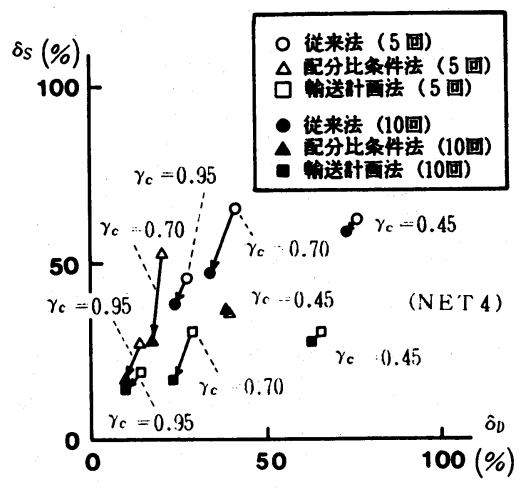

図一13分割配分回数か心推計精度に及ほす影響

図より，平均混雑率 $\gamma_{c}$ が大きい場合，分割配分 回数を多くすれば推計精度（特に， $\delta_{S}$ ）が向上す ることがわかる。これは，ODペアによって異なる 詳細ネットワーク上ての最短経路を 1 本の簡略アー クで表示して配分を行うためであり，配分回数を多 くすれば，その影響が小さくなためである。 ここで，配分計算に必要な C P U時間 (FACOM-M 170-F）を比較すると，表一1のようになる。この 
表一1 简略化配尔法の計算時間の比較（分割配分回数 5 回）

\begin{tabular}{|c|c|c|c|c|}
\hline & 全域配分法 & 従来法 & 配分比条件法 & 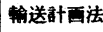 \\
\hline 計睢時間 & 11分39秒 & 6分 2私 & 6分 4秒 & 5分52私 \\
\hline 胡算機容量 & $252 \mathrm{~K}$ & $284 \mathrm{~K}$ & $293 \mathrm{~K}$ & $368 \mathrm{~K}$ \\
\hline
\end{tabular}

表より, 従来法, 配分比条件法, 輸送計画法のいず れの方法を用いても，対象道路網全体を一括に計算 する場合（全域配分法）に比へ，かなり計算時間が 短い(約半分) ことがわかる。しかし，計算機容量 を比較すると，逆に全域配分法よりも少し增加して いる。これは，今回のケーススタディの場合、メッ シュ分割数が $m_{z}=9$ ，平均ノード数が $\bar{n}=4$ $\bar{n}_{0}=0, n_{B}=8, n_{L}=4$ であり, 式 (18) は 满足するが，式（20）は満足されないためである。 このことより，本研究で提案した簡略化配分法を用 いれば，かなり計算時間の節約が可能であるといえ る。しかし，計算機容量を節約するためにはもっっ とメッシュの大きさを大きくしなければならない。

\section{5.まとめ}

本研究では，対象道路網を大きくメッシュ分割し， ネットワーク表示を簡略化することにより, 交通量 配分計算を行う 4 通りの簡略化配分法を提案した。

数値計算例を用いた検討結果をまとめると，次の ことがいえる。

（1）提案した簡略化配分法を用いれば，簡略ネッ トワーク，詳細ネットワーク，どちらのネットワー クにおいても，かなり良好な配分結果を得ることが できる。しかし，混雑率 $\gamma_{c}$ が小さい場合には，い ずれの方法も配分精度はかなり悪くなる。

（2）メッシュ分割数が少ない場合には，配分比条 件法が有効と思われる。

（3）分割配分回数を多くすれば，簡略化による誤 差を小さくすることができる。

（4）輸送計画法はプログラム作成が容易であり, 実用的手法としての発展の余地がある。

（5）全域を対象とした分割配分法に比へ，計算時 間の大幅な節約が実現できる。

ここでは示さなかったが，対象地域全体をすべて 簡略化して配分計算を行うのではなく，いま着目し ている計画対象地域はそのまま詳細ネットワークと して残し，それ以外の地域を簡略化して配分計算を
行うことも可能である。なお，今回の配分計算では 方法論の有用性を检証することが主目的であるので 単綶な分割配分法を用いている。

このように，本研究で提案した簡略化配分法は単 に計算時間の節約だけではなく，簡略道路網に対し ても，また詳細道路網に対しても，かなり良好な配 分精度で配分できることが示された。しかし，平均 混雑率が小さい場合には，問題点を残しているため

（1）簡略ネットワークでの配分に確率配分を導入 し，配分経路を增やすことにより，簡略ネットワー クでの配分誤差を小さくする，（2）メッシュ分割 数あるいは分割形状と推計誤差の関係を解明する, などの検討を行うことが今後の課題である。

\section{参考文献}

1) T.C.Hu; A Decomposition Algorithm for Shortest Paths in a Network ,Operations Research .Vol.16.1968

2）林，林，野口; 階首的経路探索を用いた大規模道路網配 分計算の簡略化手法, 土木学会年講，第 4 部、1982年

3) C.F.Daganzo; An equilibrium algorithm for the spatial aggregation problem of traffic assign ment. Transpn.Res..Vo1.14, pp.221 228.1980

4) 内山，禗田；階居化手法によるネットワークアサインメ ント，土木学会年講、第 4 部, pp. $393 \sim 394.1982$ 年

5）枝村，森律，木下，橧口; 配分対象道路作成の自動化。 第 3 回土木計画学研究発表会講演集. 1981年

6) C.F.Daganzo ; On the traffic assignment problem wi th flow dependent cost-I . II. Transpn.Res.. Vol. 11, pp.433 441,1977

7) J.C.Tanner,et al ; A strategic model for urban transport planning. Paper presented at The Planning \& Transport Research \& Computation Symposium on "Urban Traffic Models Research" .Integrated Models Seminar, London (May) . 1972

8) G.F.Newell ; Traffic Flow on Transportation Networks The MIT Press Cambridge. Massachusetes, and London

9) Litinas N. and Ben-Akiva M. ; Simplified Transp ortation Policy Anali-sis using Continuous Distributions ,Transpn. Res.. Vol.16 .1982

10）飯田，高山，名倉 ; ネットワーク表示の简略化による交 通量配分，土木学会年講、第 4 部，1982年

11）飯田，高山，橋本；ネットワーク表示の簡略化による交 通量配分の特性分析，土木学会年講，第 4 部，1983年

12）飯田，高山，横山；ネットワーク表示の简略化による交 通量配分計算法，土木学会年溝，第 4 部、1984年 